\title{
Prologue: The "Learned" Physician. On the History of an Ideal
}

Western medicine changed fundamentally during the Middle Ages, with farreaching effects on the development of the healing arts for centuries to come and ultimately to the present day. Medicine became an academic discipline. It established itself at the newly founded universities. ${ }^{1}$ Today, this position is taken for granted. It is widely acknowledged that an adequate diagnosis and treatment of the various human diseases calls for a highly differentiated theoretical foundation, on the basis of a comprehensive and sophisticated knowledge of physiological and pathological processes in the body. As soon as we widen our perspective and look at the many different cultures on our planet, in the past as in the present, however, we quickly see that Western culture with its appreciation of an "academic", theory-based, scientific medicine is exceptional. In all known cultures and societies there are diseases, and there are people who concern themselves with diagnosing and treating them. And in the vast majority of cultures, medical practice is guided by more or less complex ideas of the human body and its relation to the social, the natural, and the supernatural environment, and it is in the hands of people who are believed to possess special knowledge and skill in the area. Yet, on a global scale, the conviction that medical practice requires a comprehensive, written methodological and theoretical foundation and that a true doctor must be a "learned man" is not the rule but the exception. It is found only in the few so-called "advanced civilizations" that put special emphasis on the written word and book knowledge on the whole, civilizations which moreover, it has been shown, have sometimes had a mutual influence on each other.

The German term for physician “Arzt”, too, did not originally denote a studied, scholarly physician exclusively. The term likely derives from the Greek word "archiatros", which referred to a prominent member of a group of healers. Early modern physicians still sometimes used the term "Archiater" in this sense, thus giving a kind of honorary title to the leading local doctor. Even in the late Middle Ages, however, many who were honored with the title of an "Arzt" had not studied medicine. A barber-surgeon or surgeon trained in medicine as a craft, for

1 For useful overviews see O’Malley, Medical Education (1970), pp. 89-102; Bylebyl, Medicine (1985); Siraisi, Medieval \& early Renaissance medicine (1990), ch. 3: Medical education; Siraisi, Fakultät (1996), pp. 321-342; Siraisi, Medicine (2001); Grendler, Universities (2002), pp. 314-352; Mugnai Carrara/Forti, L'insegnamento (2008).

Ә Open Access. (c) 2022 Michael Stolberg, published by De Gruyter. (cc) BY-NC-ND This work is licensed under the Creative Commons Attribution-NonCommercial-NoDerivatives 4.0 International License. https://doi.org/10.1515/9783110733549-001 
example, could also be referred to as an "Arzt". ${ }^{2}$ Only in the course of the early modern period did the term "Arzt" become a term which was reserved for the academically trained "doctor medicinae" and ultimately the simple term "doctor", without the added "medicinae", came to refer to the university-educated physician. Over the early modern period, in a further twist, "doctor" became synonymous to some degree, in turn, with "medical practitioner" in general and ordinary people also began to call non-academic healers such as itinerant practitioners, hangmen, and barber-surgeons "doctors". 3

Within Western culture, the ideal of "learned" medicine that rests on a scientific and philosophical foundation and on extensive reading is embedded in a millennia-old tradition. ${ }^{4}$ The claim that a physician also needed to be a "philosopher" is already found in the writings of Hippocrates. This was an expression of the close connection between medicine and natural philosophy. For instance, the ancient doctrine of the body's four natural humors - yellow and black bile, blood, and phlegm, with their corresponding and paired primary qualities (hot, cold, dry, moist) - was linked directly to the ancient natural-philosophical theory of the four elements and their qualities of which all things found in nature were made up, with the various combinations of elements and qualities giving rise to specific natural properties.

Of more consequence still than the transmission of specific explanatory elements was the methodological approach that had likewise been adopted from natural philosophy in antiquity. The ancient medical writers created a theoretical edifice which allowed them to explain and treat diseases in naturalistic terms. Even a disease like epilepsy, to use a famous example, which in antiquity was largely understood as supernatural, caused by the gods, was subsequently attributed in an almost mechanistic way to processes that took place inside the head, namely to the disrupted drainage of phlegm from the brain. ${ }^{5}$ As heirs of this tradition, we may consider a naturalistic approach to be self-evident. But it is not. In many cultures, gods and other supernatural powers that are often and to varying degrees described in anthropomorphic terms continue to be central to the interpretation and treatment of illnesses.

Even in the Western world, the naturalistic approach was for a long time rivalled by other approaches. The notion that illnesses had supernatural causes or could at least be treated with supernatural means remained alive and well, for example in Asclepian medicine, which was practiced until late antiquity,

2 Kintzinger, Status (2000), pp. 68f.

3 Cod. 11205, fol. 272r.

4 See Jouanna, Entstehung (1996) and Jouanna, Hippocrates (2000).

5 Temkin, Falling sickness (1971). 
not only in the Greece but also in places like the Rhineland. It continued to shape the medical ideas and practices of the rural population into the nineteenth century at least. The "naturalistic" approach of Hippocratic medicine, however, informed medical writers for centuries. In the second century of our calendar, Galen of Pergamon elaborated this program of a medicine based on the theory of natural philosophy in numerous writings. He also expanded it by granting a pivotal role not only to the humors but also to the pneuma and the innate vital heat as well as to the individual organs and their faculties. Through his writings, he would have a leading role in the development of Western medicine for about 1500 years to come. ${ }^{6}$

In the late ancient and early medieval West after the collapse of the Roman Empire, learned medicine was passed on and practiced mainly in the monasteries with their libraries and scriptoria. ${ }^{7}$ During the same period, the heritage of learned ancient medicine was cultivated and passed down to a far greater extent in the advanced cultures of the Middle East, where it was also enriched with elements of Greek, Arab, and Persian philosophy. ${ }^{8}$ The joining of these two traditions, the European, initially predominantly monastic, and the Arab and Persian tradition, would still shape Western medicine centuries later, when, during the High Middle Ages, the first cathedral schools and universities were established. ${ }^{9}$ Above all in the areas of contact between Western and Arab cultures, in southern Italy and Spain, extensive translation activity took place. The works of Avicenna, Averroes, and Ḥunain ibn Ishāa (Iohannitius) took their place in libraries next to those of Hippocrates, Galen and the other Greek and Roman authorities. Initially known mostly for its successful practitioners, the famous school of Salerno, located near Montecassino with its vast library, increasingly adopted a highly differentiated theoretical and philosophical foundation. ${ }^{10}$

For our historical understanding it is moreover important to realize that medical subjects and especially medical theory were also discussed and taught in places other than faculties of medicine. They were taught at cathedral schools and later at universities as part of the study of the liberal arts. Even in some grammar schools, students were given the opportunity to learn from medical writings. Fourteen-year-old Isaak Keller in Strasbourg, for example, read not only excerpts

6 Galen, Opera (1822); Temkin, Galenism (1973); Hankinson, Cambridge companion (2008).

7 MacKinney, Medical education (1955), p. 844.

8 Ullmann, Medizin (1970); Pormann/Savage Smith, Medieval Islamic medicine (2007).

9 The history of universities in Europe has been studied by numerous scholars. For a survey of the developments in the sixteenth century see the contributions to Ridder-Symoens, University (1996).

10 De Renzi, Collectio (1852-59). 
from Cicero's speeches and the dialogue between Aeschines and Demosthenes in Greek, but also Galen's De sanitate tuenda. ${ }^{11}$ This was the case even more so for the gymnasia illustria, founded in the sixteenth century in some cities. These institutions occupied a place between the grammar schools and the universities, and the local municipal physician often taught classes there. ${ }^{12}$ It was sometimes physicians, in fact, who made the explicit demand for such classes to be held. In the opinion of Johann Ludwig Havenreuter of Strasbourg, medicine was to be taught at school no less than the other subjects. ${ }^{13}$

It was nevertheless far from obvious that learned medicine and those who taught and practiced it would gain a foothold at universities such as those of Bologna, Montpellier, Paris and Padua, which were among the earliest universities and for a long time the dominant ones. Medical knowledge, after all, was always connected to its application: to diagnosing, preventing, and treating diseases. In academic disputes over the hierarchy of disciplines, especially between physicians and jurists, the claim that medicine was a scientia was bitterly contested for centuries, with some saying that it only deserved the lesser rank of an art or craft (techne). Even leading medical teachers like Jacobus Sylvius conceded that medicine was a scientia only in a wider, more general sense. $^{14}$

Ultimately decisive for medicine's successful establishment in academia was its proximity to the philosophy of Aristotle, whose position at the medieval universities towered above everything else. The Galenic writings as well as Avicenna's Canon medicinae, which became the leading medical textbook in the High Middle Ages, ${ }^{15}$ were shaped by Aristotle. In fact, it was physicians more than anyone else who during the thirteenth and fourteenth centuries underlined the importance of Aristotelian philosophy. ${ }^{16}$

Subsuming medical subjects under the teaching of the liberal arts made a lot of sense in some respects. There was a great deal of overlap between the issues and questions of medicine and those of natural philosophy. The human being was part of nature and resembled other living beings in many respects. In De sensu et sensatu (436a-b) Aristotle had explicitly demanded that natural philosophy

11 Letter to Bonifacius Amerbach, 12 September 1544, edited in Jenny, Amerbachkorrespondenz (1967), pp. 47f. (www.aerztebriefe.de/id/00007426, S. Krauss/S. Schlegelmilch).

12 My thanks to Sabine Schlegelmilch for pointing this out to me.

13 Havenreuter, Theses (1586), thesis I.

14 Sylvius, Ordo (1548), p. 6.

15 Siraisi, Avicenna (1987).

16 Schmitt, Aristotle (1983); Schmitt, Aristotle (1985) 
concern itself with the fundamentals of health and illness. ${ }^{17}$ In the early Middle Ages, Isidore of Seville pointed out the proximity of medicine and the artes again. According to him, medicine was a "second philosophy" ("secunda philosophia”). While, unlike philosophy, it did not address the soul but the body, it concerned itself with the whole human being. The only reason it did not count among the individual liberal arts was that it was itself based on the liberal arts in their entirety. The physician required grammar to understand what he read and put it in his own words and he required rhetoric to make arguments, and dialectics which helped him to illuminate and consider the causes of illnesses. Arithmetic and geometry, too, were useful to the physician, for example in calculating time and the calendar. Astronomy made it possible to trace the movements of the stars, which had an immediate effect on the human body. Even music proved beneficial at times. David, for example, used his art to liberate King Saul from an impure spirit, and Asclepiades healed a raging man ("phreneticus") with "symphonia". ${ }^{18}$

For their part, the learned physicians of the High Middle Ages did everything they could to underline their erudition and the broad theoretical and philosophical basis of their thinking and acting. The scholastic method came to be widely adopted in medicine as it was in many other domains. Leading physicians like Taddeo Alderotti and Pietro d'Abano concerned themselves extensively with philosophical questions, were interested in solving contradictions between the medical tradition and Aristotelian philosophy, and even discussed general moral questions. ${ }^{19}$

In the Renaissance period, the demand that medicine be based on a philosophical foundation resonated more strongly than ever before. Galen's small treatise Quod optimus medicus sit quoque philosophus, translated by none other than Erasmus of Rotterdam, was widely read. ${ }^{20}$ With great insistence, Galen demanded that a physician must also be a philosopher and have mastered the different branches of philosophy: philosophia rationalis, philosophia naturalis and even philosophia moralis. He must, based on logical observation ("logica speculatione"), recognize the nature of the body, its composition from elements, different substances ("partes similares") and organs ("partes instrumentales") as well as their functions and use for the living being. He must be familiar with different diseases and their treatment. In all that, he had to seek certain proof ("demonstratio certa"), as taught by the "ars rationalis". With regard to morality, the physician must maintain levelheadedness and must not give in to greed for money. ${ }^{21}$

17 See also Stolz, Artes-liberales-Zyklen (2004), p. 446.

18 Isidor von Sevilla, Praeclarissimum opus (1509), fol. $24 \mathrm{r}$ (book 4, ch. 13).

19 Siraisi, Taddeo Alderotti (1981).

20 Schmitt, Aristotle (1985), pp. 1-15 and pp. 271-279 (notes), here p. 2.

21 Galen, Optimus medicus (1547), pp. 27-31, cit. pp. 30f. 
These demands were echoed by the learned physicians of the sixteenth century and reflected in university teaching. With good reason, a degree in the liberal arts was usually a prerequisite for a university degree in medicine. In some places, such as Montpellier, the pertinent knowledge was tested prior to enrollment. ${ }^{22}$ At Italian universities, the artes and medicine were commonly taught in the same faculty, but here too a preparatory study of the artes was considered indispensable. As a minimal requirement, students had to continue with the liberal arts while studying medicine. When Ulrich Ellenbog enrolled at the university in Siena in April of 1504, he thought it common sense to first familiarize himself with the foundations of logic and philosophy before he turned to medicine. This was the way everyone did it, young and old, he found. ${ }^{23}$ Two years later, in the spring of 1506, he reported that he had almost completed his study of logic and was now beginning his study of medicine. ${ }^{24}$ The only philosophical subject he would continue to study was the doctrine of nature. He had already read the aphorisms of Hippocrates privately. ${ }^{25}$ In Padua as well, sixteenth-century students of medicine did more than hear medical lectures and see anatomical demonstrations. The Zurich medical student Georg Keller, for example, studied Aristotelian logic in much detail and attended the philosophy lectures of the Padua professor Bernardino Tomitano. ${ }^{26}$ In his letters, medical student Johannes Greiffenhagen gave as much attention to the commentary on Aristotle by Francesco Piccolomini and Jacopo Zabarella as he did to the activities at the faculty of medicine and the latest publications of Girolamo Mercuriale. ${ }^{27}$ In the 1590s, Galileo Galilei deliberately held his lectures in mathematics at a time in the evening when no one else was lecturing, so that students of both medicine and philosophy could attend. By Galileo's account, the majority of his listeners were students of medicine. ${ }^{28}$ Most of those students who earned their doctoral degree in Padua or at another Italian

22 Stolberg, Studying medicine [2022].

23 Allen, Letters (1907), pp. 740-754, here pp. 741f.; on Bologna see Simeoni, Storia (1940), p. 30 .

24 On medical teaching in Siena see Piccinini, Scienza (1991).

25 Ellenbog, Briefwechsel (1938), p. 16, summary of Ellenbog's letter of 8 March 1506.

26 Schieß, Briefe (1906), p. 10.

27 Letter from Johannes Greiffenhagen to Sigismund Schnitzer, Padua, 27 June 1589, printed in: Hornung, Cista ([1626]), pp. 289f.; a preceding letter on the commentators of Aristotle's works seems to have gone lost.

28 Archivio di Stato, Venice, Riformatori allo Studio 419, letter from Galileo Galilei to the Riformatori in Venice (they were responsible for the administration of the university), 9 March 1609. Galileo complained that, after seventeen years of teaching, his students suddenly had to choose between his own lecture and that of Annibal Bimbiolo who had started to lecture at the same hour, without permission. 
university consequently obtained a double degree, receiving the title of doctor of philosophy and medicine, which these graduates later proudly underlined in their letters and publications.

Given this situation, Georg Handsch, as we learn from his Padua notebooks, had to resort to certain tricks in order to earn his doctoral degree in medicine. While he had had thorough training in the studia humanitatis, he did not even have the title of a baccalaureus to show for himself, not to mention that of a magister. As his private notes tell us, he therefore had the idea of having letters sent from his home country that addressed him as "magister". Furthermore, he was going to write a panegyric for the famous professor and ducal physician Antonio Musa Brasavola (1500-1555) in Ferrara. ${ }^{29}$ He was, by all appearances, successful. In June of 1553, he completed his studies, earning his doctoral degree in Ferrara under Brasavola. ${ }^{30}$

The study of the artes offered more than a thorough training in philosophy, rhetoric, and the art of debating, which was useful to future physicians. It also gave students some of the knowledge and skills that were useful for the study of medicine and for later professional life as a physician: natural history offered diverse insights into the world of plants, animals, and minerals, which were also used to make medicines. Mathematical skills helped with calculating birth horoscopes (nativities) and creating astrological calendars for a town (usually for the physician's place of residence), for a particular longitude and latitude. Physicians were among the major authors of astrological calendars, one of the most widely sold products of the printing press at the time. ${ }^{31}$ Some town physicians published such a calendar for their place of activity every year. ${ }^{32}$

There was furthermore quite an overlap between philosophy and medicine in academic teaching in the sixteenth century, especially at the Italian universities. With medicine and the artes being at home in one and the same faculty, personal exchange necessarily took place. Moreover many a university career at the time led from a lesser regarded and lesser paid chair in philosophy to medicine. At the University of Bologna, for example, professors tended to first teach logic and then philosophy for a number of years before they eventually were given a chair

29 In Handsch's manuscript collection of his poems, there is a eulogy on Brasavola, which he recited on the occasion of his doctoral exam in 1553 (Cod. 11210, fol. 174a v; see also Cod. 9821, fol. 243v).

30 Pardi, Titoli (1901), pp. 166f.

31 Sudhoff, Iatromathematiker (1902); Herbst, Biobibliographisches Handbuch (https://www. presseforschung.uni-bremen.de/dokuwiki/doku.php?id=startseite).

32 E.g., in Zürich, Christoph Clauser (Wehrli, Clauser (1924), pp. 84-98). 
of medicine. ${ }^{33}$ Some philosophers studied medical subjects thoroughly. For example Jacopo Zabarella, one of the most influential Aristotelians of his time, sought to find ways of establishing a stringent, logical rationale to guide medical diagnostics and therapy. He put great emphasis on the significance of an analytical course of action, a methodus resolutiva, for medicine: from the symptoms, the physician must conclude the cause. In a second movement of thought, the physician could reverse his direction and, performing a regressus, arrive at an even more precise understanding of the symptoms from his knowledge of the cause of the disease. ${ }^{34}$ There is much to suggest that Zabarella for his part was influenced by the Padua physicians of medicine. Most notably, Giovanni Battista da Monte, decades before Zabarella, cultivated a strict methodical procedure to be followed at the bedside and taught his students to draw from their observations of individual patients and from the changes and complaints the patient was reporting to identify and understand the pathological changes and processes that were taking place inside the body. ${ }^{35}$

During the sixteenth century, philosophy and medicine were also closely linked north of the Alps, where the two disciplines were commonly taught in separate faculties. As in Italy, many a German professor of medicine started out teaching the artes. Philipp Melanchthon's De anima was among the works that reached far beyond the scope of medicine and philosophy, and it was one of the most influential treatises of the period. In formal respects, the work was conceived as a commentary on Aristotle's doctrine of the soul, yet it offered anatomical and physiological knowledge on a broad scale. ${ }^{36}$ As can be seen from the repeated references to it in Handsch's Padua lecture notes, De anima also received an early reception in Italy. ${ }^{37}$

33 Thus, Benedetto Vittore, taught logic in Bologna for two years and philosophy for another six before he took the chair of medicina theorica in 1512; like him Virgilio Gherardi and Jacopo Pacini moved from logic to philosophy and finally medicine (Mazzetti, Repertorio (1847), p. 321, p. 147, p. 230).

34 On Zabarella's logic see Mikkeli, Aristotelean response (1992); Ingegno, Astrologia (1995), pp. 85-113.

35 Da Monte, Consultationum (1554); Da Monte, Consultationum (1556); Da Monte, Consultationum (1558); Da Monte, Consultationum (1559); Da Monte, Consultationum (1565). Many of Da Monte's “consultationes" were judgements on individual patients he delivered orally and which his students recorded on paper.

36 Melanchthon, Commentarius (1540); Melanchthon, Liber (1552); cf. Helm, Galenrezeption (1996) and idem, Aristotelismus (1997).

37 E.g. Cod. 11210, fol. $4 \mathrm{r}$ and fol. 34r. 